A Journal of Culture, English Language, Teaching \& Literature ISSN 1414-3320 (Print), ISSN 2502-4914 (Online)

$$
\text { Vol. } 18 \text { No.1; July } 2018
$$

Copyright (C) Soegijapranata Catholic University, Indonesia

PACA (Predicting And Confirming Activity) Reading Strategies to Promote Students' Teaching Strategy in TEFL 1 Class

${ }^{1}$ Ririn Ambarini, ${ }^{2}$ Listyaning Sumardiyani, and ${ }^{3}$ Subur Laksmono Wardoyo

English Education Department, Faculty of Language and Arts Education, Universitas PGRI Semarang, Semarang, Indonesia

email: ${ }^{1}$ ririnambarini@upgris.ac.idi yiyien.averros@gmail.com;

${ }^{2}$ listyaningsmd@gmail.com; ${ }^{3}$ subur_wardoyo@yahoo.com

Received: 29-03-2017

Accepted: 02-04-2017

Published: 27-07-2018 


\title{
PACA (Predicting And Confirming Activity) Reading Strategies to Promote Students' Teaching Strategy in TEFL 1 Class
}

\author{
${ }^{1}$ Ririn Ambarini, ${ }^{2}$ Listyaning Sumardiyani, and ${ }^{3}$ Subur \\ Laksmono Wardoyo \\ ${ }^{1}$ ririnambarini@upgris.ac.id; yiyien.averros@gmail.com; \\ ${ }^{2}$ listyaningsmd@gmail.com; ${ }^{3}$ subur_wardoyo@yahoo.com \\ ${ }^{1,2,3}$ English Education Department, Faculty of Language and \\ Arts Education, Universitas PGRI Semarang, Indonesia
}

\begin{abstract}
This research is based on the study which is attempted to examine the use of PACA reading strategies to promote students' teaching strategies in TEFL 1 class. The objectives of this study are (1) To find out the students' teaching strategies in TEFL I class before using PACA reading strategies, (2) To find out the significant difference between the students who use PACA reading strategies and those who do not use PACA reading strategies in their capability of teaching strategies in TEFL I class. The population of this study is the fifth semester students of English Department in PGRI University of Semarang. There are six classes of TEFL I class in English Department and two classes are taken as the sample of the study. The classes are $5 \mathrm{G}$ and $5 \mathrm{H}$. They are divided into the experimental class $(5 \mathrm{G})$ and the control group $(5 \mathrm{H})$. The result of the study shows that the students in the experimental class which were taught by using the technique of PACA Reading strategies to promote their teaching strategies had better achievement than the students in the control group which were taught without using the technique of PACA reading strategies. The average score of the pre-test of the experimental class was 76.72 and the control class was 72.85 . The average score of the experimental class was 81.98 and the control class was 72.85. The pre-test and the post-test score then were calculated to get the t-test to know whether there was significant difference between the experimental class and the control class. The t-test was 0.47 and the t-table was 0.213 . Then the $t$-test and t-table were compared. The data shows that the t-test was higher than the $t$ table. It means that there was significant difference between the experimental class and the control class.
\end{abstract}


Key words: PACA reading srategies, teaching methods and strategies, TEFL.

Abstrak: Penelitian ini didasarkan pada penelitian yang menguji penggunaan strategi Membaca PACA untuk meningkatkan strategi pengajaran siswa di kelas TEFL. Tujuan dari penelitian ini adalah (1) Untuk mengetahui strategi pengajaran di kelas TEFL 1 sebelum menggunakan strategi membaca PACA, (2) Untuk mengetahui perbedaan yang signifikan antara mahasiswa yang menggunakan strategi membaca PACA dan yang tidak menggunakan Strategi membaca PACA dalam kemampuan menerapkan strategi mengajar di kelas TEFL 1. Populasi penelitian ini adalah mahasiswa semester lima Jurusan Bahasa Inggris di IKIP PGRI Semarang. Ada enam kelas TEFL 1 di Jurusan Bahasa Inggris dan dua kelas diambil sebagai sampel penelitian yaitu kelas $5 \mathrm{G}$ dan $5 \mathrm{H}$ sebagai kelas eksperimen (5G) dan kelompok kontrol (5H). Hasil penelitian menunjukkan bahwa mahasiswa di kelas eksperimen yang diajarkan dengan menggunakan teknik strategi Membaca PACA untuk meningkatkan strategi pengajaran memiliki prestasi yang lebih baik daripada mahasiswa dalam kelompok kontrol yang diajarkan tanpa menggunakan teknik strategi membaca PACA. Skor ratarata pre-test kelas eksperimen adalah 76.72 dan kelas kontrol adalah 72.85. Nilai rata-rata kelas eksperimen adalah 81,98 dan kelas kontrol adalah 72,85.

Skor pre-test dan post-test kemudian dihitung untuk mendapatkan t-test untuk mengetahui apakah ada perbedaan yang signifikan antara kelas eksperimen dan kelas kontrol. Uji-t adalah 0,47 dan t-tabel adalah 0,213. Kemudian t-test dan t-tabel dibandingkan. Data menunjukkan bahwa t-test lebih tinggi dari t-tabel. Ini berarti ada perbedaan signifikan antara kelas eksperimen dan kelas kontrol.

Kata kunci: strategi membaca PACA, metode dan strategi pembelajaran, TEFL 


\section{INTRODUCTION}

Reading is the most important skill for foreign language learners, because they have little exposure to the target language outside the classroom and most of the information in English comes through reading (Danasasmita, 2007). In such contexts, students get more opportunities to read rather than to listen to English (ibid). This is why the main emphasis in most programs of English as a Foreign Language (EFL) is usually on the written skills especially reading. Amaya (2001) states that "ii]n many parts of the world a reading knowledge of a foreign language is often important to academic studies, professional success, and personal development. This is particularly true of English as so much professional, technical and scientific literature is published in English".

Teaching English as a Foreign Language (TEFL) involves teaching English to those whose first language is not English, either in the UK or overseas in differrent types of organisations. The term TEFL is associated with the teaching theory, qualification, and careers. In the TEFL 1 class of English Department of PGRI University of Semarang, according to the course outline designed for semester five, TEFL 1 constituent with TEFL 2 course that contain materials focusing on the principles of English teaching methodology.

This course deals with the basic theory of teaching English such as how to teach English through Grammar Translation Methods, Audiolingual Methods, Communicative Approach, Silent Way, Suggestopedia, Community Language Learning, and so forth. From the description above, the writer would like to observe the use of PACA reading strategies to promote students' teaching strategies in TEFL I class with the Fifth Semester Students of English Department in IKIP PGRI Semarang in the academic year 2012/2013.

\section{PREVIOUS RESEARCH FINDINGS}

There has been a number of research concerning with the use of reading strategies in teaching process. One of the studies was conducted by Stevens, et al in Nunan (2000). He revealed that students work on cooperative groups significantly outperformed on standardized measures of reading comprehension, reading vocabulary, language mechanics, language expression, and spelling. They also performed better on writing sample and oral reading measures. 
Another study was conducted by Vianty (2007). In her research entitled "The Comparison of Students' Use of Metacognitive Reading Strategies between Reading in Bahasa Indonesia and in English", she said that the use of metacognitive reading strategies is a very important thing. It is used to encourage the students to use the metacognitive reading strategies so that they are able to improve their reading performance both in Bahasa Indonesia and in English.

The next study that was conducted by Al-Tamimi (2006) entitled "The Effect of Direct Reading Strategy Instruction on Students' Reading Comprehension, Metacognitive Strategy Awareness, and Reading Attitudes among The Eleventh Grade Students in Yemen". He said that the use of Direct Strategy Instruction is very useful to be applied in the teaching and learning process. It is used to encourage the students to use the Direct Reading Strategy so that they are able to improve their reading comprehension, metacognitive knowledge and reading attitudes.

The other study was that conducted by Wallace (2005) entitled "The Impact of Implementing Four Specific Reading Strategies (Outlining, SQ3R, PLAN, and PACA) on the High School Geography Classroom”. In her research, she said that the use of the four reading strategies (Outlining, SQ3R, PLAN, and PACA) is very useful to be applied in the teaching and learning process. It is used to encourage the students to apply those strategies to their geography readings as well as to expository texts in other disciplines so that they are able to determine what is important, summarize material, recognize fact from opinion and continue to develop critical thinking skills.

Based on the previous research findings above, the writer would like to use PACA reading strategies to promote students' teaching strategies in TEFL class for the Fifth Semester Students of English Department in PGRI University of Semarang.

\section{LITERATURE REVIEW}

\section{A. Reading strategies}

There are some principles of reading that underlie the implementation of reading strategies (Pinnell \& Fountas, 1998; Stern, 1983). Those principles are: (1) students need to understand the aims of reading so that they will be able to understand and enjoy the reading activities, (2) students need to learn 
and understand the structure of written language so as to get the information and new ideas, (3) students need to know the language sounds, enjoy the sounds, and use the knowledge of using the language sounds as the means to be an illiterate person, (4) students should have lots of experience about the sound symbols so that they are able to use that experience to read and write, (5) students need to deepen the meaning of words so that they can take the advantage of it to catch the information from their reading activities effectively and efficiently, (6) students have to develo the suppleness and articulateness to improve the understanding so that reading activities will be both the joy and the enjoyment for them (Rayner, Foorman, Perfetti, Pesetsky, \& Seidenberg, 2001, p. 4).

Reading is the most important skill for foreign language learners, because they have little exposure to the target language outside the classroom and most of the information in English comes through reading (Hoffman, Baumann \& Afterbach, 2000). Rayner et al. (2001) states that "in many parts of the world a reading knowledge of a foreign language is often important to academic studies, professional success, and personal development. This is particularly true of English as so much professional, technical and scientific literature is published in English" (Richards \& Rodgers, 2003).

At school, teachers can only provide some guidance, but they cannot provide students with all the information that they need. The best service that teachers could provide their students is to teach them reading strategies that might help them become independent readers so that they are able to access all types of materials on their own (Scrivener, 1994).

According to Delgado (2005, p. 6), there are lots of reading strategies that can be applied in the process of teaching learning so that students will get more undertanding and also comprehension toward the content of the texts they are reading. Those reading strategies are as follows:

1. Anticipation Guide,

2. Chunking the Text,

3. Close Reading,

4. Dialectic Journal,

5. Graphic Organizer,

6. Guided Reading,

7. Interactive Reading Guide,

8. K-W-L Chart (What I ... Know, Want to Know, Learned),

9. Making the Text,

10. Predicting,

11. Previewing, 
52 Celt: A Journal of Culture, English Language Teaching \& Literature, Volume 18, Number 1, July 2018, pp. 47 - 63

12. Quetioning the Text,

13. Quickwrite,

14. Read Aloud,

15. Skimming/Scanning,

16. Summarize/Paraphrase/Retell,

17. Think Aloud,

18. Visualizing,

19. Activate Prior Knowledge,

20. RAFT (Role, Audience, Format, Topic),

21. PACA (Predicting and Confirming Activity),

22.TP-CASTT (Title, Paraphrase, Connotation/Denotation, Attitude, Shift, Theme, Titles),

23.SOAPSTone (Subject, Occasion, Audience, Purpose, Speaker, Tone)

\section{B. PACA reading strategy}

Active readers often use a reading strategy called PACA. PACA stands for Predicting And Confirming Activity. The strategy is based on the idea that a reader can often predict what a selection will be about. After the prediction is made, the students can look for information that confirms whether they are right or wrong. What they find out can help them understand their reading (Kinsella, 2001, p. 6).

The PACA uses student predictions to set a purpose for reading. Students make these predictions based on an initial set of information provided by the teacher, even if they have very little knowledge about the topic to be studied. Given additional information, students can revise their predictions (or hypotheses) and pose them as questions to be answered during reading (Kinsella, 2001).

Those steps are as follows:

Step 1: Predict what you will read.

Step 2: Read and confirm your predictions.

Step 3: Support your predictions

\section{Teaching strategies in TEFL class}

1. What is a good English teacher?

According to Sisman \& Acat (2003) and Woods, Jeffrey, Troman, \& Boyle (1997), a good language teacher is characterized by: 
a) Technical knowledge-understanding linguistics; grasping basic principles of language learning and teaching; language proficiencies in speaking, reading, writing and listening; knowledge about language learning process through one's own experience; understanding the relationship between culture and language and knowledge of latest development of language teaching and learning.

b) Pedagogical skills--well-informed language teaching approaches; teaching techniques; ability in lesson plan design and other classroom behavior management skills.

c) Interpersonal skills.

d) Personal qualities.

\section{English teaching presentation}

Oral presentations are becoming a more important part of language teaching, especially in the university environment. The focus of the class is often on the specific language for presentation, the use of visuals and organisation. This focus is usually determined by the lecturer. Nevertheless, in this day of student-centered teaching approaches, it is important to also know what students actually want out of a presentation class and if we as lecturers are meeting these objectives in our courses and with the textbooks we are using. Students overwhelmingly view presentation classes as an opportunity to improve their English ability rather than actually learn how to give presntations. (Miles, 2009; Dillon \& Maguire, 1997; ERIC, 2000; Sisman, 2001)

Presentation skills can be defined as those which are limited in use to presentations only and not transferable to oral communication or conversation. From this definition, we can conclude that PowerPoint skills would be defined as a presentation skill as they are not normally used in conversation related to language skills improving their speaking, and improving their English.

What this shows is that both students and teachers/lecturers seem to see the purpose or focus of oral presentations in terms of language improvement, not as a means to actually learn how to present in English. (Miles, 2009). This is especially important when one considers that giving oral presentation means that the students are able to present what they have already learned about the content of the materials about teaching methods in the classroom where they 
54 Celt: A Journal of Culture, English Language Teaching \& Literature, Volume 18, Number 1, July 2018, pp. 47 - 63

could learn how to present them in English (Katchen, 2004; Gottlieb, S., 2004).

Based on the above theories, as a part of having the scores of the students in TEFL I class, the students are assigned to be able to give their ideas of teaching methods and the examples of activities of those certain teaching methods in the presentation session. In this kind of performance test that is taken as the pre-test in the research, the students will give their best performance by presenting the best PowerPoint to explain and explore their ideas about certain teaching methods, by giving the appropriate examples of the related teaching methods. They will also be documenting their presentation with videotaping so that they can learn what kind of improvement they have made for the next performance tests in the presentation session and teaching practice session (Hanušová, 2004; Isman, 2003).

\section{Teaching strategies in TEFL class using PACA reading strategy}

There are several methods and approaches in foreign language teaching. Some of them are more widely spread and put in practice than the others. The main characteristics of methods and approaches in foreign language teaching, together with their positive and negative aspects etc. were presented - as to the future teachers - in one of the Methodology courses (ESL Glossary, 2012; Ananthakrishnan, 1993; Oddens, 2004).

Incorporating the usage of the Communicative Approach into the teaching process means developing the learners' communicative competence (=an ability to use the language appropriate to a given social context) and avoidance of learners' mother tongue in classes (Larsen-Freeman, 1986; Baytekin, 2004). The development of methodology is connected with the development of methods and approaches in the foreign language teaching as we know them nowadays.

In the Longman Dictionary of Applied Linguistics, methodology is defined as: (1) The study of the practices and procedures used in teaching, and the principles and beliefs that underlie them, and (2) Such practices, procedures, principles, and beliefs themselves. One can, for example criticize or praise the methodology of a particular language course." (Nunan, 2000; Beydogan, 2002; Bircan, 2003). The use of the learners' mother tongue should be eliminated but it is sometimes very hard or 
even impossible; when teaching beginners using the target language only it is often the case that the learners do not understand everything (Harmer, 1995; Bowen, 2006; Celep, 2001; Otto-Van. 2004; Richard, 2006). In this case, it is the teacher's task to explain the learners the advantages of this way of teaching and to support the learners' motivation.

\section{RESEARCH METHOD}

\section{A. The research design}

Degu \& Yigzaw (2006) stated that experimental means systematical method to build causal-effect relationship. The researchers have to manage situation where some variables impact into one or more dependent variables that could be identified.

In this study, the research team used pretest-posttest, control design. The design of the experiment could be described as follows:
Experimental group
$\mathrm{R}$
$\mathrm{O}_{1} \quad \mathrm{X}$
$\mathrm{O}_{2}$
Control group
$\mathrm{R}$
$\mathrm{O}_{3}$
$\mathrm{O}_{4}$

\section{B. Population}

In an experimental design, there should be a population that will be investigated. Patton (1990) stated that a population is any group of individuals that have one or more characteristics in common that are of interest to the researcher. The population in this study is the fifth semester students of English Department in PGRI University of Semarang in the academic year $2012 / 2013$. The class consists of two classes with the total number of students are 90 students. Each class consists of 45 students.

\section{Sample}

Sample is the part of the amount and characteristics from its population (Patton, 1990). It is a part of population to be investigated by a researcher to do the research easily. Sample of the research is taken from the total number of population.

This research used simple random sampling. It is called simple because in deciding sample from the population as randomly without carrying the class or 
level from its population. The population in this research is all the students of English Department in PGRI University of Semarang. There are three classes from the fifth semester. The researcher team chooses class $5 \mathrm{G}$ as the experimental group and class $5 \mathrm{H}$ as the control group. The total number of the students from those classes are 90 . They are 45 from class $5 \mathrm{G}$ and 45 from class $5 \mathrm{H}$.

\section{The research variables}

Independent variables are the condition or characteristics that the experimenter manipulates in her or his attempt to ascertain their relationship to observe phenomena (Cresswell, 2003). Based on the definition, the independent variable of the study is the methods of teaching using PACA reading strategies.

Dependent variables are the conditions or characteristics that appear, disappear, or change as the experimenter introduces, removes, or changes independent variable (Cresswell, 2003). Based on the definition, the dependent variable of this study is the students' achievement in teaching strategies.

\section{E. The instrument for collecting the data}

The researcher team uses one test type. It is a kind of performance test in the form of presentation and teaching practice. This type of test is chosen because the researchers have to check the students' teaching strategies in implementing the methods of teaching they have already learned during joining TEFL 1 class in the presentation session and in the teaching practice session.

Teaching practice is a test to measure the student's ability in teaching. Before they practice teaching, they must know the methods of teaching they have already learned and understood with or without using PACA reading strategy. Students' capability in giving presentation about the theory of teaching methods and giving the examples of teaching learning activities based on those methods will be measured by rubric- English teaching presentation and the capability of the students in implementing the methods of teaching as the teaching strategies in their teaching practice will be measured by rubricmicroteaching. 


\section{RESEARCH FINDINGS}

After the students in the experimental class were taught by using PACA Reading Strategies, they used those strategies to understand more the materials of teaching methods in TEFL 1 class. Then, they analized the materials of teaching methods, made them into power point, and presented them in front of the class in the form of presentation where they would present not olnly about the characteristics of teaching methods, but also the advantages and the disadvantages of the teaching methods together with the examples of the class activities how those teaching methods could be applied in teaching practise. The scores of the students' presentation about the teaching methods learned in TEFL 1 class were used as the score of their pre-test.

There is a significant difference between the pre-test and the post-test. It means that the students of the experimental class that were taught how to use PACA Reading Strategies to analize the materials of teaching methods in TEFL I class and to improve their teaching strategies in TEFL 1 class had an improvement of 7.88. The scoring of the students' teaching practice was used as the score of their post test. The result shows that the average of the scores of the pre-test was 75.38 and the average of the scores of the post-test was 83.26.

Based on the data above, we can see there is no significant difference between the pre-test and the post-test, even the students of the control group were low after they got the post-test. The control class that were taught without using the technique of PACA reading strategies to analize the materials of teaching methods in TEFL 1 Class and to improve their capability of teaching practice related to the implementation of the theory of teaching methods they had done in the presentation had the difference mean $5.53(78.38-72.85)$.

The mean of the post-test scores of the experimental class and the control class had a significant difference. The mean score of the experimental class was 83.36 and the mean score of the control class was 78.38. It means that the mean scores of the experimental class is higher than the control class. The improvement of the mean of the post-test of the experimental class and the control class was 4.98.In addition, the improvement of the mean of the experimental class was 19.94. It can be calculted from $\mathrm{M}_{\mathrm{x} 2}-\mathrm{M}_{\mathrm{x} 1}=83.87-$ $75.38=8.49$. The improvement of the mean of the control class was 5.53. It can be calculated from $\mathrm{M}_{\mathrm{y} 2}-\mathrm{M}_{\mathrm{y} 1}=78.38-72.85=5.53$.

If t-test $\leq \mathrm{t}$-table, it means that there is no difference ability between the experimental group and the control group in the students' teaching strategies using the technique of PACA reading strategies to analize the materials of 
teaching methods in TEFL 1 class and to improve the teaching strategies as the implementation of the theory of the materials they had done in the presentation in TEFL I class. The t-table value for $\alpha=5 \%$, with $\mathrm{df}=\mathrm{N}_{\mathrm{x}}+\mathrm{N}_{\mathrm{y}}$ $2=45+41-2=84$, is 0.213 . Based on that result, the $t$-value $>t$-table where $0.47>0.213$. Thus, there is a significant difference in the students' ability in the students' teaching strategies in TEFL 1 class between the experimental group and the control group.

\section{DISCUSSION}

The ability of the students in teaching strategies in TEFL 1 clas who were taught by using the technique of PACA reading strategies to analize the materials of teaching methods and to promote teaching strategies is sufficient. The researcher used that method to improve the students' ability in the performance of teaching strategies. The students can share their ideas of teaching methods and teaching activities creatively without being ashamed. They were interested and happy in the learning way. Based on these facts, the scores of the students who were taught by using the technique of PACA reading strategies to analize the content of the teaching methods in TEFL 1 class materials are good.

It can be seen from the result of the mean score of the post test in the experimental group which was taught by using the technique of PACA reading strategies to analize the materials of teaching methods and to promote teaching practice, which are 83.26. It can be seen from the result of mean score of the post test in the control group which was taught without using the teachnique of PACA reading strategies to improve their performance in the presentation session and in the teaching practice session, which are 78.38.

It was caused that the students who did not use the technique of PACA reading strategies in analyzing the materials of teaching methods got lack of understanding to elaborate the teaching methods into the significant activities during the process of teaching learning. The students' ability in the presentation session and teaching practice session which was taught using the technique of PACA reading strategies to understand more the materials of teaching mehtods in TEFL 1 class was different from the students' ability in the presentation session and teaching practice session which was taught by using the technique of PACA reading strategies to understand more the materials of teaching mehtods in TEFL 1 class. 
It can be seen from the final score of both classes. The mean score of the experimental class is higher than the mean score of the control class. The mean score of the post-test of the experimental class was 83.26 and the mean score of the pot-test of the control class was 78.38. These results present the significant difference in the presentation session and in the teaching practice session, because $t_{\text {value }}$ is higher than $t_{\text {table, }}$ which is $t_{.05}=0.213(0.47>0.213)$.

\section{CONCLUSION}

The mean of the students who were taught by using the technique of PACA reading strategies to understand more the materials of teaching methods in TEFL I class and to promote the students' teaching strategies for the pre-test was 75.38 and this score belongs to the low scores. The mean of the students who were taught by using the technique of PACA reading strategies for the post-test was 83.26 and it belongs to the good scores.

The mean of the students who were taught without using the technique of PACA reading strategies for the pre-test was 72.85 and this score belongs to the low scores. The mean of the students who were taught without using the technique of PACA reading strategies for the post-test was 78.38 and it belongs to the low scores.

\section{SUGGESTIONS}

This study has shown that PACA reading strategies was an appropriate method in improving the students ability in the presentation session where they have to give the information of certain teaching techniques/methods including the examples of activities in the classroom and in the teaching practice session where the students should be able to practise how to teach the students with certain materials according to the syllabus of the related school level and with the appropriate activities based on the teaching methods they have presented in the presentation session. They can be more creatively and freely in giving and sharing their ideas and thoughts by discussing each others' teaching methods and classroom activities both in the presentation session and teaching practice session.

Since the use of PACA reading strategies can improve the students ability in the presentation of certain teaching methods in TEFL 1 class materials and in the teaching practice session, it is suggested that the lecturers 
of TEFL 1 use this method as an alternative method in teaching the materials

of TEFL 1 about the teaching methods in English class so that the students will get much more better understanding about the content of the materials about how to elaborate the teaching methods and create the classroom activities based on the appropriate teachinng methods. Moreover, the students can share their ideas freely without being ashamed.

They also have so many ideas or thoughts related to the certain teaching methods they had already learned and give the examples of classroom activities based on those methods, and then in the teaching practice session, they will be able to create the classroom management including the opening, the content, and the closing of the classroom activities. It can make their teaching performance good and even better.

The next researchers must be able to give more improvement in the use of the technique of PACA reading strategies because it can improve the students' ability in the presentation session about elaborating the teaching methods in TEFL 1 class and in the teaching practice about implementing the classroom activities based on the appropriate teaching methods they have already learned.

Based on this study, we can say that the use of PACA reading strategies is an effective method in improving the students' capabilities both in the presentation session and in the teaching materials in TEFL 1class. It is, therefore, suggested that the institution gives information or training for the lecturers of TEFL 1 in using PACA Reading strategies in TEFL 1 class so that the students will be able to improve their abilities in understanding the materials related to teaching methods used in teaching English as a foreign language so that they will get better performance and also scores in the presentation session and in the teaching practice session.

\section{REFERENCES}

Al-Tamimi, N. O. (2006). The effect of direct reading strategy instruction on students' reading comprehension, metacognitive strategy awareness, and reading attitudes among eleventh grade students in Yemen (Unpublished doctoral dissertation, University Sains Malaysia). 
Ambarini, R., Sumardiyani, L., \&Wardoyo, S.L., PACA Reading Strategies to

Promote Students' Teaching Strategy in TEFL 1 Class

Amaya, M. J. (2001). Implementing a content-based language teaching programme. In G. Sánchez (Ed.). Present and Future Trends in TEFL. Almería: Universidad de Almería, 135-165.

Ananthakrishnan, N. (1993). Microteaching as a Vehicle of Teacher Training-its Advantages-Disadvantages. Journal Postgraduate Medicine, 39(3), 142.

Baytekin, C.. (2004). Learning Teaching Techniques and Material Development. Ankara: Ani Yayincilik.

Beydogan, Ö. (2002). Changes in teaching strategies and the changing role of teachers. Çă̆daş Ĕ̈itim, 27(287), 34-39.

Bircan, I. (2003). New Directions in Education: Elementary School Teacher education in Developed Countries. Sivas: Cumhuriyet Üniversitesi.

Bowen, T. (2006). Methodology Challenge. The Communicative Classroom. Onestopenglish, Macmillan.

Celep, C. (2001). Teacher-Student Relationship in Classroom Management. Çă̆daş Ĕ̈itim, 26(272), 19-24.

Creswell, J. W. (2003). Research Design: Qualitative, Quantitative, and Mixed Methods Approaches (2 $2^{\text {nd }}$ ed.). Sage Thousand Oaks.

Danasasmita, W. (2007). Efektivitas Model Directed Reading Actvity (DRA) Dalam Pengajaran Membaca Bahasa Indonesia Sebagai Bahasa Asing [The Effectiveness of the Directed Reading Activity (DRA) Model in Teaching Indonesian Reading as a Foreign Language]. Jurnal Educationist, 1(2).

Degu, G., \& Yigzaw, T. (2006). Research Methodology: Lecture Notes for Health Science Students. Addis Ababa: The Carter Center (Ethiopian Public Health Training Initiative), 45-50.

Delgado, J. (2005). Engaging Strategies for All Students: The SpringBoard Reading Strategies. New York: The College Board.

Dillon, J., \& Maguire, M. (Eds.). (1997). Becoming a Teacher. Issues in Secondary. Buckingham: Open University Press.

ERIC. (2000). Making large Classes More Interactive. No. EJ610221. 
Volume 18, Number 1, July 2018, pp. 47 - 63

ESL Glossary. ESL Glossary: Definitions of common ESL/EFI terms: Communicative Approach. Retrieved on 25 October, 2012 from www.bogglesworld.com/glossary/communicativeapproach.htm

Gottlieb, S. (2004). Innovative Assessment in Competency Based Student Centered Learning. Adapazari, Sakarya: Esentepe Campus of Sakarya University.

Hanušová, S. (2004). Methodology: The Grammar-Translation Method. Faculty of Education, Brno.

Harmer, J. (1995). The Practice of English Language Teaching. Harlow: Longman House.

Hoffman, J.V., Baumann, J.F., \& Afterbach, P. (2000). Balancing Principles for Teaching Elementary Reading. New Jersey: Lawrence Erbaum Publkisher.

Isman, A. (2003). Teaching Technologies and Material Development. Istanbul: Degişim.

Katchen, J. E. (2004). Teaching Presentation Skills Using Video as Role Model. In Proceedings of the MOE Conference on "Developing the Basics of Holistic General Education (pp. 41-50). Xinfeng, Hsinchu: MingHsin University of Science and Technology.

Kinsella, K. (2001). Mathematics Reading Strategies. California: Globe Fearon, Pearson Learning Group.

Larsen-Freeman, D. (1986). Teachiques and Principles in Language Teaching. Oxford: Oxford University Press.

Miles, R. (2009). Oral Presentation for English Proficiency Purposes. Reflections on English Language Teaching Journal, 8(2), 103-110.

Nunan, D. (2000). Language Teaching Methodology: A textbook for teachers. London: Pearson Education Ltd.

Oddens, D. A. M. (2004). Trend in Ducth Vocational Education Teacher Training in Terms of Personal Quality. In International Conference on VET Teacher Training (Vol. 1, pp.347-354). Ankara: SVET.

Otto-Van. (2004). Oral Presentation Rubric. Leistungskuis English K13/,2004/06 (Numberger). Van Taube Gymnasium. 
Patton, M. Q. (1990). Qualitative evaluation and research methods. LondonNewbury Park, New Delhi: SAGE Publications, Inc.

Pinnell, G. S., \& Fountas, I.C. (1998). Word Matterrs; Teaching Phonics and Spelling in the Reading/Writing Classroom. Portsmouth, NH: Heinemann.

Rayner, K., Foorman, B. R., Perfetti, C. A., Pesetsky, D., \& Seidenberg, M. S. (2001). How psychological science informs the teaching of reading. Psychological science in the public interest, 2(2), 31-74.

Richard. (2006). Total Physical Response. British Council: BBC World Service. Retrieved

from www.teachingenglish.org.uk/think/methodology/tpr.shtml

Richards, J. C., \& Rodgers, T. S. (2003). Approaches and methods in language teaching. Cambridge university press.

Scrivener, J. (1994). Learning Teaching. Oxford: Macmillan Publisher Limited, $1-19$.

Sisman, M. \& Acat, B. (2003). The Effect of Teaching Practicum on the Perception of Teaching Prtofession. Firat Üniversitesi Sosyal Bilimler Dergisi, 13(1), 235-250.

Sisman, M. (2001). Introduction to Teaching. Ankara: Pegema Yaytnctltk.

Stern, H. H. (1983). Fundamental Concepts of Language Teaching. Oxford University Press.

Vianty, M. (2007). The Comparison of Students' Use of Metacognitive Reading Strategies between Reading in Bahasa Indonesia and in English. International Education Journal, 8(20), 449-460.

Wallace, A. E. (2005). The Impact of Implementing Four Specific Reading Strategies (Outlining, SQ3R, PLAN, and PACA) On the High School Geography Classroom. Shawnee Mission East High School. Shawnee Mission Board of Education.

Woods, P., Jeffrey, B., Troman, G. \& Boyle, M. (1997). Restructuring Schools, Reconstructing Teachers. Buckingham: Open University Press. 